\title{
Experiences of noninvasive ventilation in adults with hypercapnic respiratory failure: a review of evidence
}

\author{
Hamadziripi Ngandu, Nichola Gale and Jane B. Hopkinson \\ Affiliation: School of Healthcare Sciences, Cardiff University, Cardiff, UK.
}

Correspondence: Hamadziripi Ngandu, School of Healthcare Sciences, Cardiff University, Eastgate House, 35-43, Newport Road, Cardiff, CF24 OAB, UK. E-mail: nganduhQcardiff.ac.uk

ABSTRACT Noninvasive ventilation (NIV) has been shown to be beneficial for patients with respiratory failure; however, many patients fail to tolerate it and require other interventions. The objective of this thematic synthesis was to describe the nature of NIV experiences in adults with hypercapnic respiratory failure. A systematic, computerised literature search of English-language databases was undertaken with no restriction on date of publication. A total of 99 papers was identified and screened for eligibility from databases including CINAHL, Medline and PsycINFO, and some were hand searched. 45 papers were critically appraised and 32 met our inclusion criteria. Thematic analysis identified six key themes: benefits of NIV; fear (of various categories, namely, fear of technology/mask, fear of death and dying, and fear of pain and suffering); adaptation to NIV machine; decision making; need for information; and relationship with healthcare professionals. For people using NIV treatment, the experience of being on the NIV machine is unexpected and can be stressful. Findings from this review offer healthcare professionals insights and understanding into the patient experience of NIV. Healthcare professionals may use these findings to implement new strategies in NIV provision and the exploration of the applicability of age-specific supportive care NIV guidelines.

@ERSpublications

There is a need for research into the experiences of NIV in older people with hypercapnic respiratory failure http://ow.ly/10onBl

\section{Introduction}

Noninvasive ventilation (NIV) is an established treatment for hypercapnic respiratory failure (HRF) in older people in whom endotracheal intubation may not provide long-term benefits. A widely used definition of NIV is the delivery of mechanical ventilation without the use of an invasive artificial airway (endotracheal or tracheostomy tube) [1,2]. HRF is defined as alveolar hypoventilation characterised by low levels of oxygen (hypoxia) and high levels of carbon dioxide (hypercapnia) $[3,4]$.

The use of NIV in HRF has been extensively researched since its inception, with a gradual improvement in the quality of the research produced. A meta-analysis of in-hospital trials for chronic obstructive pulmonary disease has shown that NIV is associated with reduced mortality and reduces the need for intubation [5]. KeEnAN et al. [6] found that the use of NIV decreased the need for endotracheal intubation by $38 \%$ and reduced mortality by $16 \%$, leading to lower costs per patient admission. Despite the

This article has supplementary material available from err.ersjournals.com

Received: Jan 132016 | Accepted after revision: March 212016

Support statement: This study was undertaken as part of lead author's research project for his postgraduate research degree at Cardiff University. H. Ngandu received a studentship from the Research Capacity Building Collaboration Wales in an open, peer-reviewed process. Funding information for this article has been deposited with the Open Funder Registry.

Conflict of interest: Disclosures can be found alongside this article at err.ersjournals.com

Provenance: Submitted article, peer reviewed.

Copyright OERS 2016. ERR articles are open access and distributed under the terms of the Creative Commons Attribution Non-Commercial Licence 4.0. 
effectiveness of NIV in treating patients with HRF, older people present a large population of patients who have difficulties with NIV treatment acceptance as compared to young adults $[7,8]$. The reasons for this difficulty, individual experiences and treatment preferences of older people receiving NIV remain unclear.

In the past, there has been emphasis on quantitative research designs in NIV treatment resulting in a significant lack of literature on the experiences of older people with HRF. There is need for a review of existing work about the experience of people with HRF receiving NIV [9].

\section{Purpose}

The aim of this review was to conduct a thematic synthesis of available qualitative studies that examined NIV experiences of adult people, regardless of the setting, age or the mode of NIV treatment. To our knowledge, there is no literature available that examines the NIV experiences of older people with HRF in acute settings. Therefore, broadening study selection was considered appropriate to provide a general perspective into the experiences of NIV in adult people with respiratory failure.

\section{Methods}

\section{Search strategy}

A systematic, computerised literature search of the electronic databases CINAHL, Medline (the primary database of the US National Library of Medicine) and PsycINFO (American Psychological Association), with PubMed as the search engine, was carried out in 2013 and updated in 2015 [10]. No restrictions of sex or date of publication were imposed; however, only studies written in English were considered. Publications that may have been missed were identified by searching the tables of contents of key respiratory journals (Chest, Thorax and the BMJ, the European Respiratory Journal, Respiratory Research, and the American Journal of Respiratory and Critical Care Medicine) and reference lists of articles identified as relevant were also reviewed by hand searching. Databases were searched using Boolean operators, field codes, truncation $\left(^{\star}\right)$, wildcards (?) and quotation marks. The search was limited to articles that include an abstract and research articles only (supplementary table S1).

\section{Study selection}

Qualitative studies that provided insights into experiences of people aged 18 years and older who were receiving NIV treatment or had just been weaned off were included. Pre-defined inclusion and exclusion criteria were used (table 1). Studies were included if they: described the experience of being on continuous positive airway pressure (CPAP) or bilevel positive airway pressure (BiPAP) therapy; used qualitative methods or mixed methods with a qualitative section that met the inclusion criteria; were written in English; and were peer reviewed. The application of CPAP is usually on a long-term basis and BiPAP, which is used in people with acute HRF, is similar; hence, the inclusion of people using CPAP on long-term basis. Studies were not included if they: reported views of healthcare professionals and carers only, or children; or focussed on people receiving invasive ventilation. Study selection was broadened to include relevant studies linked to experiences of older people undergoing NIV.

\section{Appraisal process/quality assessment}

There are no universally accepted criteria by which to evaluate the quality of qualitative research studies and debate continues about the appropriateness of applying evaluation techniques primarily developed for reviewing quantitative research to reviews of qualitative research [11-13]. Nevertheless, qualitative studies for this review were assessed for methodological quality prior to inclusion in the review in accordance with the Critical Appraisal Skills Programme tool. Qualitative papers for this study were categorised using hierarchy of evidence for qualitative research [14]. This approach uses four levels of hierarchy: generalisable studies (level I), conceptual studies (level II), descriptive studies (level III) and single case studies (level IV) (table S1). The hierarchy of evidence used to evaluate literature retrieved for the purpose of this study does not include quantitative studies because it is specific to qualitative research methods.

\section{Thematic analysis}

The review was undertaken using the thematic synthesis approach as outlined by THOMAS and HARDEN [15]. Thematic synthesis involves the identification of important or recurrent themes. The synthesis was in three stages, which overlapped to some degree: the free line-by-line coding of the findings of primary studies; the organisation of these "free codes" into related areas to construct "descriptive" themes; and the development of "analytical" themes [15]. Findings are summarised under thematic headings.

\section{Studies identified}

A total of 1423 results were identified, and after screening and removing duplicates, 99 full-text articles were retrieved. 45 studies were considered eligible and after reading the full articles, another 13 articles were 
Table 1 Inclusion and exclusion criteria

Criteria

Inclusion

Studies with a focus on adult (18 years and older) people's experiences of NIV treatment, using either an acute BiPAP machine or a CPAP machine

Studies of populations of adults receiving NIV treatment on a short-term (using acute BiPAP) or long-term basis (using CPAP)

Studies using qualitative methods or mixed methods with a qualitative section that met the inclusion criteria

Studies written in English and that were peer reviewed

\section{Exclusion}

Studies that reported views of healthcare professionals and carers only, or children

Studies that focussed on experiences of people receiving invasive ventilation (e.g. tracheostomy)
Rationale

Studies that examined the experiences of NIV treatment in older people have been very limited; therefore, broadening the search to include all NIV studies with an adult population was considered, in order to provide a general perspective into the experiences NIV in people with respiratory failure

To broaden the search, because there are no available studies that focus on older people receiving NIV via BiPAP in acute setting. Broadening the study selection provided relevant studies linked to older people's experiences of undergoing NIV treatment

The review focused on the views of people undergoing NIV treatment, for which qualitative or mixed methods studies are appropriate

Due to limited time and resources, and possible translation errors, non-English language studies were not included

Our review concerns NIV experiences as lived by the people undergoing treatment

Application, design and function of invasive ventilation differ markedly from NIV; therefore, it was considered that treatment experiences may be different

NIV: noninvasive ventilation; BiPAP: bilevel positive airway pressure; CPAP: continuous positive airway pressure.

excluded because they did not meet the criteria or they were not presented as research articles (e.g. discussion papers). One study [16] was excluded since it only had an abstract in English with the full document written in German. Another study [17] provided an abstract but the full article was unavailable. The remaining 32 studies were considered relevant for thematic analysis and were included in the review. The Preferred Reporting Items for Systematic Reviews and Meta-Analyses (PRISMA) guidelines was used in preparing this paper [18]. PRISMA has a 27-item checklist, and a four-phase study flow diagram reporting identification, screening, eligibility and inclusion. PRISMA checklist items that could not be used in this review, for example, questions 13 about summary measures and 21 about meta-analysis, are not presented. Figure 1 shows the flow of studies through the search process, including the rationale for exclusion [19]

\section{Studies included}

The description and underpinning philosophy of all the studies varied significantly. Some studies clearly followed a particular theory through the analysis process, giving clarity and implying rigour in the data. Most studies used phenomenology, of which one utilised interpretive phenomenological analysis, five descriptive phenomenology with bracketing and two hermeneutics. Two studies by the same authors and another two from different authors used grounded theory [20-22]. One used a sequential explanatory mixed method, which employed quantitative methods and then a qualitative study [23], whilst another study used a concurrent nested mixed-method design in their longitudinal study [24]. Three studies that were very similar used almost the same sample [25-27]; as such, findings from these publications were used but categorised as one study.

All qualitative studies used interviews, with variations in the details given. Some interviews were semistructured, with examples of questions given; others were open-ended. Findings were clearly presented and discussed in most of the studies; however, some lacked clarity in acknowledging their limitations. There was variation in the way in which abstracts were presented, with some authors giving very little information. This could have been influenced by the policy of the journal and the space allocated.

The majority of the studies were Scandinavian, and conducted in a community setting on people using CPAP, as compared to eight studies that were conducted in a hospital setting. Of these eight studies, only two were undertaken on people using acute BiPAP. This may suggest that the majority of NIV treatment studies are 


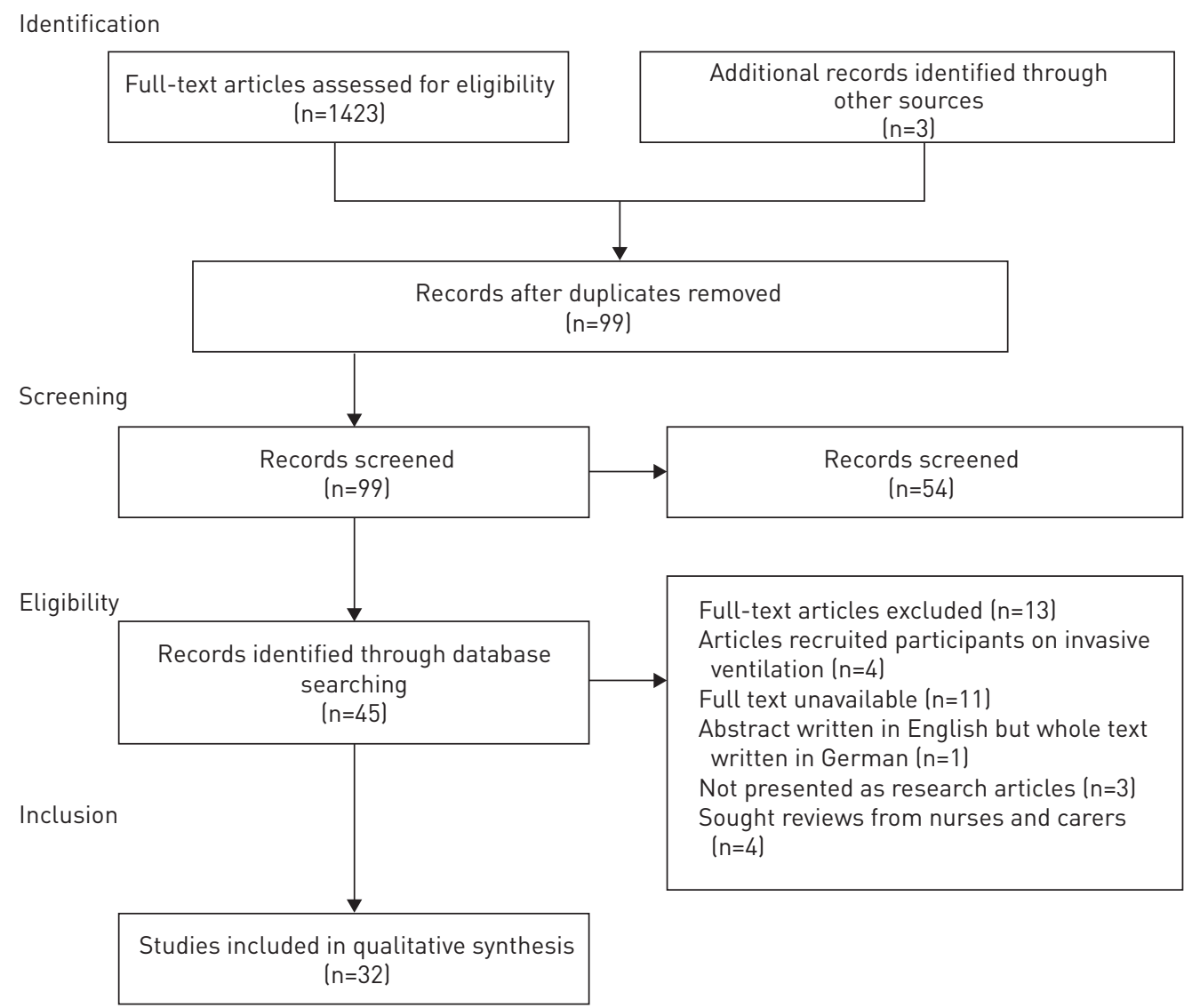

Figure 1 Preferred Reporting Items for Systematic Reviews and Meta-Analyses study flow chart.

performed with most of the participants recruited from community centres across the world. There was also variance in the representation of men and women: four studies included men only [28-31] and one study included females only [32]. The age ranges varied from 27-85 years. Cultural and ethnic differences were not described well except for one study, which refers to white/European, Southeast Asian and Middle Eastern backgrounds. A summary of the characteristics of the articles reviewed is provided in table 2 .

\section{Results}

The literature provided 285 free codes that were organised in hierarchical order under a range of 10 descriptive themes: initial reactions to NIV treatment; fear of death and dying, technology, and pain and suffering; relationships; emotional impact; hope; coping; support; information; finding meaning; and personal values. In the final synthesis stage, six analytical themes emerged: benefits of NIV; fear; adaption to the NIV machine; decision making; need for information; and relationship with health professionals. Within the key themes, there were subthemes pertaining to fear.

\section{Benefits of NIV}

The benefits of NIV are well established. In several studies, participants reported experiencing benefits from NIV treatment, mainly due to improved breathing, a sense of immediate relief, good sleeping patterns, increased alertness and less snoring [32, 34, 35, 40, 46, 47, 49]. In one study, patients described NIV treatment as a life-saving treatment, adding that it improves quality of life and that it is an absolute necessity for survival [43]. Nevertheless, findings from other studies suggest that benefits of NIV depend on the underlying condition and its influence. For example, patients who received NIV for the treatment of HRF regarded the NIV machine as a lifesaver [46] and in case of obstructive sleep apnoea [43], the ventilator was a necessity for survival. There is evidence that NIV is effective and it improves the quality of life for people with respiratory failure [53].

Despite these benefits, it is clear that most of the studies' findings identified and focused on problematic experiences of adult people undergoing NIV treatment $[22,24,27,30,33,34,50,51]$. These problematic experiences were common themes across the studies and they are explored in the next sections. 
Table 2 Studies included

\begin{tabular}{|c|c|c|c|c|c|}
\hline $\begin{array}{l}\text { First author } \\
\text { [ref.] }\end{array}$ & Topic, focus and questions & Paradigm and method & Setting and sample & Findings & Limitations \\
\hline Almeida [33] & $\begin{array}{l}\text { "Patient preferences and } \\
\text { experiences of CPAP } \\
\text { and oral appliances for } \\
\text { the treatment of } \\
\text { obstructive sleep apnea: } \\
\text { a qualitative analysis" } \\
\text { To better understand } \\
\text { patients' perspectives } \\
\text { and preferences about } \\
\text { treatment with CPAP } \\
\text { and OA devices for } \\
\text { obstructive sleep apnoea }\end{array}$ & $\begin{array}{l}\text { Qualitative } \\
\text { Qualitative analysis of four } \\
\text { focus group sessions } \\
\text { In-depth interview }\end{array}$ & $\begin{array}{l}\text { Canada } \\
\text { University of British Columbia } \\
\text { Sleep Apnea Clinic } \\
22 \text { participants ( } 13 \text { male) } \\
\text { Age } 36-85 \text { years }\end{array}$ & $\begin{array}{l}\text { Many factors impact patients' } \\
\text { experience with their treatment } \\
\text { device and that their treatment } \\
\text { needs are not only physical but } \\
\text { also relate to their lifestyle } \\
\text { The authors suggest that } \\
\text { matching therapy to patient } \\
\text { preferences may help identify } \\
\text { the most appropriate } \\
\text { treatment, and increase the } \\
\text { likelihood of adherence }\end{array}$ & $\begin{array}{l}\text { Findings may not be } \\
\text { representative of all OSA } \\
\text { patients } \\
\text { The qualitative research } \\
\text { approach used is not clearly } \\
\text { defined }\end{array}$ \\
\hline ANDo [30] & $\begin{array}{l}\text { “Experience of long-term } \\
\text { use of non-invasive } \\
\text { ventilation in motor } \\
\text { neuron disease: an } \\
\text { interpretative } \\
\text { phenomenological } \\
\text { analysis" } \\
\text { To explore patients' } \\
\text { perceptions of NIV } \\
\text { treatment evolve over } \\
\text { time and how this was } \\
\text { reflected in their } \\
\text { adherence to NIV }\end{array}$ & $\begin{array}{l}\text { Qualitative } \\
\text { Interpretative } \\
\text { phenomenological } \\
\text { analysis } \\
\text { Semistructured interviews }\end{array}$ & $\begin{array}{l}\text { UK } \\
\text { NHS neurology and } \\
\text { respiratory outpatient } \\
\text { clinics in Liverpool } \\
5 \text { patients ( } 4 \text { male) } \\
\text { Age } 51-75 \text { years }\end{array}$ & $\begin{array}{l}\text { Physical benefits gained from NIV } \\
\text { were direct precipitators of } \\
\text { psychological gains } \\
\text { A more positive attitude was seen } \\
\text { in individuals who appreciated } \\
\text { gains in energy and } \\
\text { empowerment, while a more } \\
\text { negative attitude was } \\
\text { associated with perceptions of } \\
\text { hopelessness over the future } \\
\text { A reinforced approach to NIV was } \\
\text { observed when the essentiality } \\
\text { of NIV was acknowledged and } \\
\text { this was sometimes } \\
\text { accompanied by fear of death }\end{array}$ & $\begin{array}{l}\text { Small sample } \\
\text { Interviews were normally } \\
\text { conducted verbally } \\
\text { Some strategies were } \\
\text { employed to mitigate } \\
\text { communication difficulties } \\
\text { with patients who had } \\
\text { dysarthria but the strategies } \\
\text { are not specified }\end{array}$ \\
\hline Ando [34] & $\begin{array}{l}\text { "Why don't they accept } \\
\text { non-invasive ventilation? } \\
\text { Insight into the } \\
\text { interpersonal } \\
\text { perspectives of patients } \\
\text { with motor neurone } \\
\text { disease" } \\
\text { To understand why some } \\
\text { MND patients decline or } \\
\text { withdraw from NIV }\end{array}$ & $\begin{array}{l}\text { IPA } \\
\text { Semistructured interviews }\end{array}$ & $\begin{array}{l}\text { UK } \\
9 \text { patients with } \\
\text { MND (7 male) } \\
\text { Age } 40-79 \text { years }\end{array}$ & $\begin{array}{l}\text { Four themes were identified: } \\
\text { preservation of the self, } \\
\text { negative perceptions of NIV, } \\
\text { negative experience with } \\
\text { healthcare services, and not } \\
\text { needing } \\
\text { NIV } \\
\text { Further analysis identified the } \\
\text { fundamental issue to be the } \\
\text { maintenance of perceived self, } \\
\text { which was interpreted to } \\
\text { consist of the sense of } \\
\text { autonomy, dignity and QoL }\end{array}$ & $\begin{array}{l}\text { Only patients who had declined } \\
\text { or withdrawn from NIV } \\
\text { treatment at an early stage } \\
\text { were interviewed } \\
\text { It would be informative to } \\
\text { include patients who declined } \\
\text { the treatment in different } \\
\text { stages of NIV use }\end{array}$ \\
\hline
\end{tabular}




\begin{tabular}{|c|c|c|c|c|c|}
\hline $\begin{array}{l}\text { First author } \\
\text { [ref.] }\end{array}$ & Topic, focus and questions & Paradigm and method & Setting and sample & Findings & Limitations \\
\hline ANDo [29] & $\begin{array}{l}\text { "Exploring reasons for } \\
\text { declining and } \\
\text { withdrawing from } \\
\text { non-invasive ventilation } \\
\text { among motor neurone } \\
\text { disease patients" } \\
\text { To understand why some } \\
\text { individuals with MND } \\
\text { withdraw from NIV }\end{array}$ & $\begin{array}{l}\text { Qualitative } \\
\text { Phenomenological } \\
\text { approach using IPA } \\
\text { Semistructured interviews }\end{array}$ & $\begin{array}{l}\text { UK } \\
\text { Purposive sampling } \\
\text { WCNN and UHA } \\
12 \text { patients ( } 10 \text { male) } \\
\text { Age } 64-79 \text { years }\end{array}$ & $\begin{array}{l}\text { Illness could have a negative } \\
\text { impact on patients' perception } \\
\text { of themselves, consequently } \\
\text { affecting their decision over } \\
\text { NIV use } \\
\text { NIV may generate fear, which } \\
\text { may form a negative belief } \\
\text { about NIV, leading to a } \\
\text { rejection of it due to a sense of } \\
\text { the loss of control over the } \\
\text { machine } \\
\text { A poor impression of the } \\
\text { healthcare service may have } \\
\text { impact on participants' } \\
\text { willingness to engage with the } \\
\text { hospital in consideration of NIV } \\
\text { establishment } \\
\text { Individuals' understanding of } \\
\text { their condition influences } \\
\text { perception regarding the need } \\
\text { of NIV }\end{array}$ & $\begin{array}{l}\text { Less selective homogeneity } \\
\text { Only males participated } \\
\text { Novice researcher } \\
\text { (MPhil student) }\end{array}$ \\
\hline Ayow [35] & $\begin{array}{l}\text { "Factors influencing the } \\
\text { use and nonuse of } \\
\text { continuous positive } \\
\text { airway pressure therapy: } \\
\text { a comparative case } \\
\text { study" } \\
\text { To identify facilitators and } \\
\text { barriers toward CPAP } \\
\text { therapy after treatment } \\
\text { initiation among patients } \\
\text { with OSA }\end{array}$ & $\begin{array}{l}\text { Qualitative } \\
\text { Phenomenological } \\
\text { approach } \\
\text { Semistructured interviews }\end{array}$ & $\begin{array}{l}\text { Canada } \\
\text { Sleep disorder clinic } \\
\text { Purposive sampling } \\
8 \text { patients ( } 4 \text { male) } \\
\text { Age } 43-48 \text { years }\end{array}$ & $\begin{array}{l}\text { Social comparison and stigma } \\
\text { influenced patients in either } \\
\text { using or abandoning CPAP } \\
\text { Absence of supportive } \\
\text { relationship can be a factor } \\
\text { toward not using NIV for most } \\
\text { patients }\end{array}$ & $\begin{array}{l}\text { Theoretical saturation did } \\
\text { not occur due to limited } \\
\text { resources }\end{array}$ \\
\hline BAKKER [36] & $\begin{array}{l}\text { “Continuous positive } \\
\text { airway pressure } \\
\text { treatment for obstructive } \\
\text { sleep apnoea: Maori, } \\
\text { Pacific and New Zealand } \\
\text { European experiences” } \\
\text { To explore Maori, Pacific } \\
\text { and NZ European } \\
\text { patients' experience of } \\
\text { CPAP treatment }\end{array}$ & $\begin{array}{l}\text { Qualitative } \\
\text { Ethnography } \\
\text { Semistructured interviews }\end{array}$ & $\begin{array}{l}\text { New Zealand } \\
\text { Community sleep } \\
\text { investigation centre, } \\
\text { purposive sample. } \\
5 \text { Maori , } 5 \text { Pacific, and } 8 \mathrm{NZ} \\
\text { Europeans } \\
\text { Age } 30-71 \text { years }\end{array}$ & $\begin{array}{l}\text { Patients in all three groups } \\
\text { reported that they had little } \\
\text { knowledge of OSA or CPAP } \\
\text { prior to treatment initiation } \\
\text { All groups identified barriers to } \\
\text { treatment (both at the CPAP } \\
\text { initiation phase and long term), } \\
\text { reported feelings of being } \\
\text { "overwhelmed" with } \\
\text { information during the initial } \\
\text { CPAP education session and } \\
\text { discussed the importance of } \\
\text { successful role models }\end{array}$ & $\begin{array}{l}\text { Sleep service model used at } \\
\text { the centre is not used } \\
\text { throughout New Zealand }\end{array}$ \\
\hline
\end{tabular}


Table 2 Continued

\begin{tabular}{|c|c|c|c|c|c|}
\hline $\begin{array}{l}\text { First author } \\
\text { [ref.] }\end{array}$ & Topic, focus and questions & Paradigm and method & Setting and sample & Findings & Limitations \\
\hline BALLANGRUd [37] & $\begin{array}{l}\text { “Clients' experiences of } \\
\text { living at home with a } \\
\text { mechanical ventilator" } \\
\text { To explore how patients } \\
\text { experience living with } \\
\text { home mechanical } \\
\text { ventilation and how they } \\
\text { experience care and } \\
\text { supervision of } \\
\text { healthcare personnel }\end{array}$ & $\begin{array}{l}\text { Inductive qualitative } \\
\text { approach } \\
\text { Interviews/telephone }\end{array}$ & $\begin{array}{l}\text { Norway } \\
\text { Community setting } \\
10 \text { patients ( } 7 \text { male) } \\
\text { Age } 18-75 \text { years }\end{array}$ & $\begin{array}{l}\text { Two main themes emerged } \\
\text { Theme } 1 \\
\text { Having a home ventilator } \\
\text { enhances QoL: } \\
\text { "a life worth living" } \\
\text { The ventilator treatment } \\
\text { builds up strength and } \\
\text { improves wellbeing } \\
\text { Participants emphasised } \\
\text { that it was important to } \\
\text { feel in control of their } \\
\text { own situation and had } \\
\text { an overriding wish to } \\
\text { live a normal and } \\
\text { active life } \\
\text { Theme } 2 \\
\text { Competence and } \\
\text { continuity of healthcare } \\
\text { personnel are factors } \\
\text { for success } \\
\text { The experience was that } \\
\text { competence and } \\
\text { follow-up by healthcare } \\
\text { personnel varied, and } \\
\text { that good quality } \\
\text { teaching and } \\
\text { information were } \\
\text { important }\end{array}$ & $\begin{array}{l}\text { Four out of } 10 \text { participants } \\
\text { received respiratory support } \\
\text { via a tracheostomy } \\
\text { The study does not give } \\
\text { separate data from those } \\
\text { who used invasive } \\
\text { ventilation and NIV } \\
\text { The experience of using a } \\
\text { mask could be different } \\
\text { from that of not } \\
\text { using a mask }\end{array}$ \\
\hline BROSTRÖM [38] & $\begin{array}{l}\text { "Putative facilitators and } \\
\text { barriers for adherence } \\
\text { to CPAP treatment in } \\
\text { patients with obstructive } \\
\text { sleep apnea syndrome: } \\
\text { a qualitative analysis" } \\
\text { To explore the experiences } \\
\text { of adherence to CPAP } \\
\text { treatment in patients } \\
\text { with OSA syndrome }\end{array}$ & $\begin{array}{l}\text { Qualitative } \\
\text { Explorative inductive } \\
\quad \text { approach } \\
\text { Semistructured interviews }\end{array}$ & $\begin{array}{l}\text { Sweden } \\
\text { CPAP clinics, one university } \\
\text { hospital and one county } \\
\text { hospital } \\
\text { Purposive sampling } \\
23 \text { patients ( } 13 \text { male) } \\
\text { Age } 33-74 \text { years }\end{array}$ & $\begin{array}{l}\text { Findings show that adherence to } \\
\text { CPAP treatment is a complex } \\
\text { and multifaceted problem } \\
\text { involving patient-, treatment- } \\
\text { and condition-related factors, } \\
\text { and experiences related to } \\
\text { social situation and the } \\
\text { healthcare system }\end{array}$ & $\begin{array}{l}\text { The approach used by the } \\
\text { authors does not allow for } \\
\text { quantification of the relative } \\
\text { importance (magnitude and } \\
\text { prevalence) of the individual } \\
\text { factors or how these factors } \\
\text { relate to different degrees } \\
\text { of objectively measured } \\
\text { adherence (e.g. they did not } \\
\text { know whether patients with } \\
\text { an objectively good } \\
\text { adherence described the } \\
\text { same facilitators and } \\
\text { barriers as patients with } \\
\text { objectively poor adherence) }\end{array}$ \\
\hline
\end{tabular}




\begin{tabular}{|c|c|c|c|c|c|}
\hline $\begin{array}{l}\text { First author } \\
\text { [ref.] }\end{array}$ & Topic, focus and questions & Paradigm and method & Setting and sample & Findings & Limitations \\
\hline BROSTRÖM [23] & $\begin{array}{l}\text { "A mixed method } \\
\text { evaluation of a } \\
\text { group-based educational } \\
\text { programme for CPAP } \\
\text { use in patients with } \\
\text { obstructive sleep apnea" } \\
\text { To describe adherence to } \\
\text { CPAP treatment } \\
\text { knowledge about OSA/ } \\
\text { CPAP, as well as OSA } \\
\text { patients' perceptions of } \\
\text { participating in a } \\
\text { group-based } \\
\text { programme using } \\
\text { problem-based CPAP } \\
\text { initiation }\end{array}$ & $\begin{array}{l}\text { Qualitative and quantitative } \\
\text { Sequential explanatory } \\
\text { mixed-method design } \\
\text { Medical devices or } \\
\text { self-rating scales } \\
\text { Phenomenological } \\
\text { approach } \\
\text { Semistructured interviews }\end{array}$ & $\begin{array}{l}\text { Sweden } \\
\text { Linkoping University Hospital } \\
\text { Strategically selected } \\
25 \text { patients ( } 14 \text { male) } \\
\text { Age } 49-65 \text { years }\end{array}$ & $\begin{array}{l}\text { Patients value an adequate } \\
\text { introduction and presentation } \\
\text { of the schedule before starting } \\
\text { CPAP } \\
\text { Patients strive to become } \\
\text { adherent CPAP users } \\
\text { Patients usually have } \\
\text { negative feelings before } \\
\text { treatment, which increase } \\
\text { after having had practical } \\
\text { experience with the } \\
\text { treatment }\end{array}$ & $\begin{array}{l}\text { A large number of } \\
\text { participants suffered from } \\
\text { hypertension and other } \\
\text { comorbidities } \\
\text { This might have had an impact } \\
\text { in participant's perception } \\
\text { of the appropriateness of } \\
\text { the CPAP treatment (e.g. a } \\
\text { chance to enhance } \\
\text { alertness, reduce blood } \\
\text { pressure and alleviate } \\
\text { complications) }\end{array}$ \\
\hline DicKERSON [39] & $\begin{array}{l}\text { "Life changes in } \\
\text { individuals diagnosed } \\
\text { with sleep apnea while } \\
\text { accommodating to } \\
\text { continuous positive } \\
\text { airway pressure (CPAP) } \\
\text { devices" } \\
\text { To longitudinally discover } \\
\text { OSA patients' } \\
\text { experiences with CPAP }\end{array}$ & $\begin{array}{l}\text { Qualitative } \\
\text { Retrospective } \\
\text { Heideggerian } \\
\text { hermeneutic } \\
\text { phenomenology plus } \\
\text { pilot of Calgary OSA QoL } \\
\text { tool } \\
\text { Semistructured interviews }\end{array}$ & $\begin{array}{l}\text { USA } \\
\text { Sleep centre } \\
\text { Purposive sampling } \\
20 \text { patients ( } 9 \text { male) } \\
\text { Age } 31-72 \text { years }\end{array}$ & $\begin{array}{l}\text { Patients face the difficulties and } \\
\text { troubles acclimating to the } \\
\text { CPAP device } \\
\text { Some patients persist through } \\
\text { NIV treatment regardless of its } \\
\text { adverse effects }\end{array}$ & $\begin{array}{l}\text { The study involved a survey } \\
\text { that participants who had } \\
\text { no spouse or significant } \\
\text { other said questions related } \\
\text { to intimate relationships } \\
\text { were not appropriate }\end{array}$ \\
\hline DickERSON [40] & $\begin{array}{l}\text { "CPAP devices: } \\
\text { encouraging patients } \\
\text { with sleep apnea" } \\
\text { To understand patients' } \\
\text { experiences and } \\
\text { difficulties using CPAP }\end{array}$ & $\begin{array}{l}\text { Qualitative } \\
\text { Heideggerian hermeneutic } \\
\text { phenomenological } \\
\text { approach } \\
\text { Semistructured interviews }\end{array}$ & $\begin{array}{l}\text { USA } \\
\text { Urban medical centre and } \\
\text { rural hospital } \\
17 \text { participants ( } 12 \text { male) } \\
\text { Age } 40-73 \text { years }\end{array}$ & $\begin{array}{l}\text { New NIV patients may gain hope } \\
\text { by witnessing other patients } \\
\text { living with the NIV machine and } \\
\text { coping with the difficulties } \\
\text { Patients need practical } \\
\text { information to provide context } \\
\text { for understanding required } \\
\text { changes in lifestyle }\end{array}$ & $\begin{array}{l}\text { Investigation of experiences } \\
\text { using CPAP was limited to } \\
\text { the effect of patient support } \\
\text { group participation on } \\
\text { encouragement to use } \\
\text { CPAP }\end{array}$ \\
\hline Diмech [28] & $\begin{array}{l}\text { “Critical care patients' } \\
\text { experience of the helmet } \\
\text { continuous positive } \\
\text { airway pressure” } \\
\text { To explore critical care } \\
\text { patient's experience of } \\
\text { helmet CPAP }\end{array}$ & $\begin{array}{l}\text { Qualitative } \\
\text { Phenomenological } \\
\text { approach } \\
\text { Semistructured interviews }\end{array}$ & $\begin{array}{l}\text { UK } \\
\text { Purposive sampling } \\
\text { NHS foundation hospital } \\
\quad 6 \text { male patients } \\
\text { Age } \geqslant 18 \text { years }\end{array}$ & $\begin{array}{l}\text { Themes revealed several areas } \\
\text { that highlighted the patient's } \\
\text { experience } \\
\text { Entrapment } \\
\text { Confusion } \\
\text { "Helping me breathe" } \\
\text { Liberation } \\
\text { Relief } \\
\text { Trust } \\
\text { Endurance } \\
\text { Adaptation }\end{array}$ & $\begin{array}{l}\text { Novice researcher (MSc } \\
\text { student) } \\
\text { Only males participated } \\
\text { The study was limited to only } \\
\text { one hospital and patient } \\
\text { group }\end{array}$ \\
\hline
\end{tabular}


Table 2 Continued

\begin{tabular}{|c|c|c|c|c|c|}
\hline $\begin{array}{l}\text { First author } \\
\text { [ref.] }\end{array}$ & Topic, focus and questions & Paradigm and method & Setting and sample & Findings & Limitations \\
\hline Fung [41] & $\begin{array}{l}\text { "Human factors/usability } \\
\text { barriers to home } \\
\text { medical devices among } \\
\text { individuals with } \\
\text { disabling conditions: } \\
\text { in-depth interviews with } \\
\text { positive airway pressure } \\
\text { device users" } \\
\text { To explore in detail the } \\
\text { types of difficulties } \\
\text { experienced by patients } \\
\text { with physical/sensory } \\
\text { impairments who use } \\
\text { PAP devices, as an } \\
\text { initial step in designing } \\
\text { a questionnaire to } \\
\text { survey users about this } \\
\text { topic }\end{array}$ & $\begin{array}{l}\text { Qualitative } \\
\text { Descriptive study } \\
\text { Semistructured interviews }\end{array}$ & $\begin{array}{l}\text { USA } \\
\text { Community sleep centre, } \\
\text { purposive sample. } \\
9 \text { patients ( } 8 \text { male, } 5 \\
\text { Caucasian) } \\
\text { Age } \geqslant 50 \text { years }\end{array}$ & $\begin{array}{l}\text { Participants reported CPAP } \\
\text { devices failed to meet the } \\
\text { needs of individuals with } \\
\text { physical/sensory } \\
\text { impairments (e.g. tremor, poor } \\
\text { depth perception, paresis) by } \\
\text { requiring patients to perform } \\
\text { manually difficult tasks (e.g. } \\
\text { inserting CPAP parts through } \\
\text { small apertures, attaching } \\
\text { parts using a twisting motion } \\
\text { and lifting arms overhead to } \\
\text { apply CPAP headgear) } \\
\text { These demands contributed to } \\
\text { patients' frustration with and } \\
\text { reduced use of the home } \\
\text { medical device }\end{array}$ & $\begin{array}{l}\text { All patient participants } \\
\text { described } \\
\text { impairment-related } \\
\text { difficulty with their PAP } \\
\text { devices because } \\
\text { researchers recruited } \\
\text { patients with physical/ } \\
\text { sensory impairments who } \\
\text { use PAP devices } \\
\text { The study involved carers as } \\
\text { participants: however, it } \\
\text { does not give patients' } \\
\text { views separately, which may } \\
\text { differ from carers' }\end{array}$ \\
\hline GaLe [42] & $\begin{array}{l}\text { "Adapting to domiciliary } \\
\text { non-invasive ventilation } \\
\text { in chronic obstructive } \\
\text { pulmonary disease: a } \\
\text { qualitative interview } \\
\text { study" } \\
\text { To explore experiences of } \\
\text { domiciliary NIV in COPD, } \\
\text { to understand decision } \\
\text { making processes and } \\
\text { improve future } \\
\text { palliative care }\end{array}$ & $\begin{array}{l}\text { Constructivist grounded } \\
\text { theory } \\
\text { Semistructured interviews }\end{array}$ & $\begin{array}{l}\text { UK } \\
20 \text { COPD patients } \\
\text { Age } 52-83 \text { years }\end{array}$ & $\begin{array}{l}\text { Patients reported symptomatic } \\
\text { benefit, which generally } \\
\text { outweighed negative } \\
\text { experiences and led to } \\
\text { continued use }\end{array}$ & $\begin{array}{l}\text { The sample lacked ethnic } \\
\text { diversity; it was not } \\
\text { reflective of the local } \\
\text { population; however, it was } \\
\text { reflective of those on NIV } \\
\text { Researchers were not able to } \\
\text { return after analysis to } \\
\text { further explore themes; } \\
\text { therefore, data saturation } \\
\text { may not have been reached }\end{array}$ \\
\hline Hu [22] & $\begin{array}{l}\text { "Life experiences among } \\
\text { obstructive sleep apnoea } \\
\text { patients receiving } \\
\text { continuous positive } \\
\text { airway pressure } \\
\text { therapy" } \\
\text { To generate a descriptive } \\
\text { theoretical framework } \\
\text { for experiences among } \\
\text { OSA patients undergoing } \\
\text { CPAP therapy }\end{array}$ & $\begin{array}{l}\text { Qualitative } \\
\text { Grounded theory } \\
\text { Semistructured interviews }\end{array}$ & $\begin{array}{l}\text { Taiwan } \\
\text { Convenience sample } \\
22 \text { patients ( } 18 \text { male) } \\
\text { Age } 37-68 \text { years }\end{array}$ & $\begin{array}{l}\text { Analyses indicated seven } \\
\text { subcategories of OSA patients } \\
\text { with CPAP } \\
\text { 1) Seeking medical } \\
\text { information } \\
\text { 2) Difficulties with CPAP } \\
\text { 3) Trial and error for the } \\
\text { "right" CPAP } \\
\text { 4) Long scheduled } \\
\text { waiting times } \\
\text { 5) Wondering } \\
\text { 6) High expectations } \\
\text { 7) Getting back good health }\end{array}$ & $\begin{array}{l}\text { Limitations to the study not } \\
\text { well explored } \\
\text { Convenience sample }\end{array}$ \\
\hline
\end{tabular}


Table 2 Continued

\begin{tabular}{|c|c|c|c|c|c|}
\hline $\begin{array}{l}\text { First author } \\
\text { [ref.] }\end{array}$ & Topic, focus and questions & Paradigm and method & Setting and sample & Findings & Limitations \\
\hline INGADÓTTIR [43] & $\begin{array}{l}\text { “Technological dependency } \\
\text { - the experiences of } \\
\text { using home ventilators } \\
\text { and long-term oxygen } \\
\text { therapy: patients' and } \\
\text { families perspective" } \\
\text { To describe patients' and } \\
\text { families experience of } \\
\text { long-term home } \\
\text { treatment with NIV } \\
\text { during sleep with or } \\
\text { without additional } \\
\text { oxygen therapy }\end{array}$ & $\begin{array}{l}\text { Qualitative } \\
\text { IPA and narrative analysis } \\
\text { Semistructured interviews }\end{array}$ & $\begin{array}{l}\text { Iceland } \\
\text { Landaspitali University } \\
\text { Hospital } \\
6 \text { patients ( } 3 \text { males) } \\
\text { Age } 45-70 \text { years }\end{array}$ & $\begin{array}{l}\text { The themes that emerged from } \\
\text { the data were } \\
\text { life-saving treatment; } \\
\text { compassion and understanding } \\
\text { central amid use of complex } \\
\text { machines } \\
\text { wanting to be seen as healthy } \\
\text { dominance of } \\
\text { technological thinking } \\
\text { sustained work in maintaining } \\
\text { the treatment }\end{array}$ & $\begin{array}{l}\text { Sampling strategy is not } \\
\text { clearly discussed } \\
\text { Limitations to the study are } \\
\text { also not clearly defined }\end{array}$ \\
\hline KVANGARSNES [44] & $\begin{array}{l}\text { "Narratives of } \\
\text { breathlessness in } \\
\text { chronic obstructive } \\
\text { pulmonary disease" } \\
\text { To explore patient } \\
\text { perceptions of COPD } \\
\text { exacerbation and the } \\
\text { patients' } \\
\text { experiences of their } \\
\text { relations with health } \\
\text { personnel during care } \\
\text { and treatment }\end{array}$ & $\begin{array}{l}\text { Qualitative } \\
\text { Narrative inquiry } \\
\text { In-depth interviews }\end{array}$ & $\begin{array}{l}\text { Norway } \\
\text { ICU } \\
\text { Purposive sampling } \\
10 \text { patients ( } 5 \text { males) } \\
\text { Age } 45-85 \text { years }\end{array}$ & $\begin{array}{l}\text { Two main themes emerged } \\
\text { Breathlessness } \\
\text { Trust/power dimension } \\
\text { Breathing problems led to a } \\
\text { situation where patients } \\
\text { experienced both situation of } \\
\text { trust and power }\end{array}$ & $\begin{array}{l}\text { The first author was an } \\
\text { intensive care nurse, which } \\
\text { may have influenced the } \\
\text { interpretations } \\
\text { Interviews were transcribed and } \\
\text { then translated from } \\
\text { Norwegian into English; this } \\
\text { may have a impacted the } \\
\text { validity of the research, as the } \\
\text { context and meaning may be } \\
\text { lost in translation }\end{array}$ \\
\hline Lemoignan [45] & $\begin{array}{l}\text { "Amyotrophic lateral } \\
\text { sclerosis and assisted } \\
\text { ventilation: how patients } \\
\text { decide" } \\
\text { To elicit factors that are } \\
\text { pertinent to their } \\
\text { decision-making } \\
\text { process about assisted } \\
\text { ventilation }\end{array}$ & $\begin{array}{l}\text { Qualitative } \\
\text { Phenomenology } \\
\text { methodology } \\
\text { Semistructured interviews }\end{array}$ & $\begin{array}{l}\text { Canada } \\
\text { Canadian MND clinic } \\
\text { Maximum variation sampling } \\
\text { strategy } \\
9 \text { patients ( } 6 \text { males) } \\
\text { Age } 46-72 \text { years }\end{array}$ & $\begin{array}{l}\text { Six main themes emerged } \\
\text { relevant to decision-making } \\
\text { about assisted ventilation } \\
\text { 1) The meaning of the } \\
\text { intervention } \\
\text { 2) The importance } \\
\text { of context } \\
\text { 3) The importance } \\
\text { of values } \\
\text { 4) The effect of fear } \\
\text { 5) The need for } \\
\text { information } \\
\text { 6) Adaption to or acceptance } \\
\text { of the intervention }\end{array}$ & $\begin{array}{l}\text { The interviewer knew the } \\
\text { patients already; as such, } \\
\text { some aspects of her clinical } \\
\text { role may have influenced } \\
\text { the findings }\end{array}$ \\
\hline
\end{tabular}




\section{Table 2 Continued}

First author Topic, focus and questions Paradigm and method Setting and sample Limitations

[ref.]

"Meanings of living at

home on a ventilator"

To illuminate the

meanings of being on a

ventilator and living at

home

LINDAHL [26]

LINDAHL [27]

\author{
“On being dependent on \\ home ventilation: \\ depictions of patients \\ experience over time" \\ To describe the meanings \\ and experience of being \\ dependent on \\ mechanical ventilation \\ and living at home \\ “On becoming dependent \\ on home mechanical \\ ventilation" \\ To illuminate meanings of \\ becoming dependent on \\ home mechanical \\ ventilator treatment
}

\section{PIGGIN [46]}

\author{
"The experience of \\ non-invasive ventilation \\ in motor neurone \\ disease: a qualitative \\ exploration" \\ To explore MND patients' \\ experiences of \\ respiratory impairment \\ and NIV use
}

\begin{tabular}{|c|c|}
\hline Qualitative & Sweden \\
\hline $\begin{array}{l}\text { Phenomenological- } \\
\text { hermeneutic method }\end{array}$ & $\begin{array}{l}\text { Community setting } \\
9 \text { patients ( } 3 \text { males) }\end{array}$ \\
\hline Semistructured interviews & Age $27-72$ years \\
\hline Qualitative & Sweden \\
\hline $\begin{array}{l}\text { Phenomenological } \\
\text { hermeneutics }\end{array}$ & $\begin{array}{l}\text { Community hospital } \\
13 \text { patients ( } 8 \text { males) }\end{array}$ \\
\hline Semistructured interviews & Age $52-81$ years \\
\hline Qualitative & Sweden \\
\hline $\begin{array}{l}\text { Phenomenological } \\
\text { hermeneutics }\end{array}$ & $\begin{array}{l}\text { Hospital and community } \\
13 \text { patients ( } 8 \text { males) }\end{array}$ \\
\hline
\end{tabular}

\section{Qualitative}

Cross-sectional and

longitudinal studies

IPA

Interviews

Purposive sampling
13 patients (8 males)

UK

Community/patients' own homes.

Cross-sectional study

5 male patients

Age 60 - 72 years

Longitudinal study

26 patients (19 male)
The meanings of being on a home ventilator were interpreted as maintaining autonomy and persistence in interaction with the ventilator and other human beings, and being able to raise above oneself and one's

personal boundaries in order to live a good life

Ignorance and negative attitudes

on the part of professionals

working and/or managing care

in ventilated patients' homes

are interpreted as causing

suffering and intensifying a

closed-in mode of being

The findings imply possibilities and deficiencies in meeting patients' existential needs, such as helping them to breathe spiritually by supporting them as they get their breath after such a life-changing event as becoming dependent on a ventilator

This study found complex emotional and psychological responses to NIV, including reluctance to initiate, fear of dependence and threats to control

Respiratory masks had a significant negative impact on identity and self-esteem;

However, patients felt that the positive physical effects of NIV made this experience acceptable
Two participants were using invasive ventilation/

tracheostomy

It is difficulty to identify data from these two participants

Their experience may not have been the same as participants who used NIV

Interviews included patients who were ventilated invasively with tracheostomy Their experience may not have been the same as patients using NIV

The study had less selective homogeneity; this may have affected the findings of the study by either over- or underrepresenting the impact of the phenomenon

Two participants used invasive ventilation and most participants had varying prognosis, i.e. chest deformity, neuromuscular disorder, stroke, rheumatic disorder, spinal cord injury and obesity hypoventilation

The study was conducted in two parts: the researcher started with a

cross-sectional study as a preparative step for a subsequent longitudinal study

Study was conducted as part of a doctoral degree

The study was only limited to patients with MND 

[ref.]

SAWYeR [24]

SHOUKRY [32]

SLATER [47]
Topic, focus and questions

“Differences in perceptions of the diagnosis and

treatment of obstructive

sleep apnea and

continuous positive

airway pressure therapy

among adherers and

non-adherers"

To describe OSA patients beliefs and perceptions of the diagnosis and

CPAP treatment that

importantly differentiate

adherent from

nonadherent patients

prior to and after the

first week of treatment

when the pattern of

CPAP use is established

Treatment experience of

people with obstructive

sleep apnoea seeking

continuous positive

airways pressure device

provision through

community pharmacies

- a role for

pharmacists"

To explore the unique experiences of people with OSA who source treatment through

community pharmacies

"An investigation of the

experiences of patients

receiving non-invasive

ventilation"

To explore and

conceptualise the

experiences of patients

who had received NIV

for COPD

Setting and sample

Findings

USA

Qualitative and quantitative

Mixed-method concurrent,

nested study

Semistructured interviews

and software (RemStar

Pro ${ }^{\#}$ CPAP system)

centre

Purposive sampling

Age 41-66 years

\section{Qualitative}

Phenomenological

approach

In-depth semistructured

interviews

20 participants

Age $20-75$ years

\section{Qualitative}

Phenomenological

interpretive approach

Semistructured interviews

Community

Purposeful sampling

5 patients ( 3 male)

Age 64-82 years
15 participants $(13$ male)

Description of the meaning of being diagnosed with OSA and treatment with CPAP, which in turn influenced their decision to accept or reject treatment and the extent of CPAP use

Differences in beliefs and

perceptions at diagnosis and

with CPAP treatment were

identified among CPAP

adherers and nonadherers

Australia

Community pharmacies in greater Sydney region

rposive convenience
Study participants were predominantly male with severe OSA who had

relatively high educational backgroun

A more heterogeneous sample of OSA patients is needed to explore the

relationship of sex, disease severity, symptom perception and disease-specific literacy with CPAP adherence
There was lack of OSA awareness ensuing delayed diagnosis,

suboptimal provision of information about CPAP, and personal/psychosocial

characteristics were

predominant influences on CPAP use and positive CPAP provision experiences in community pharmacies

Physical issues

Mask unpleasant and frightening

Paternalism and patient choice

Patients receiving NIV for

AECOPD are under-consulted when treatment decisions are being made

Need for patients to have a better understanding and involvement with their treatment to promote active participation in their

own care
The demographics of the interviewing researcher (pharmacy student) may have influenced a socially desirable response about pharmacy services demonstrates potential bias as those who accepted participation may be the ones who have experienced positive experiences with the pharmacy

Novice researcher (MSc student), may have influenced patient's response

Most of the participants were known to the researcher and this may have limited criticisms of treatment for fear of any adverse effects this may have on their future care 
Table 2 Continued

\begin{tabular}{|c|c|c|c|c|c|}
\hline $\begin{array}{l}\text { First author } \\
\text { [ref.] }\end{array}$ & Topic, focus and questions & Paradigm and method & Setting and sample & Findings & Limitations \\
\hline Sørensen [20] & $\begin{array}{l}\text { "Striving for habitual } \\
\text { well-being in } \\
\text { noninvasive ventilation: a } \\
\text { grounded theory study of } \\
\text { chronic obstructive } \\
\text { pulmonary disease } \\
\text { patients with acute } \\
\text { respiratory failure" } \\
\text { To develop a theoretical } \\
\text { account of the pattern of } \\
\text { behaviour in patients } \\
\text { with ARF due to COPD } \\
\text { who undergo NIV in a } \\
\text { hospital setting }\end{array}$ & $\begin{array}{l}\text { Qualitative } \\
\text { Grounded theory } \\
\text { Observations } \\
\text { Semistructured interviews }\end{array}$ & $\begin{array}{l}\text { Denmark } \\
\text { University hospital } \\
21 \text { patients ( } 11 \text { male) } \\
\text { Age } 43-81 \text { years }\end{array}$ & $\begin{array}{l}\text { During NIV, patients' behavioural } \\
\text { patterns may relate to their } \\
\text { breathlessness, the sensation } \\
\text { of being restrained by the mask } \\
\text { and head gear, and individual } \\
\text { coping with the side-effects } \\
\text { Patients with COPD undergoing } \\
\text { NIV tend to use discomfort } \\
\text { control as a strategy and } \\
\text { drawing on routines, proactive } \\
\text { participation and mobilising } \\
\text { strength are strategies that } \\
\text { they use to achieve control }\end{array}$ & $\begin{array}{l}\text { Findings do not reflect all } \\
\text { details of the entire range } \\
\text { of behaviour and strategies } \\
\text { among COPD patients with } \\
\text { ARF }\end{array}$ \\
\hline SUNDLING [48] & $\begin{array}{l}\text { “Patients' with ALS and } \\
\text { caregivers' experiences } \\
\text { of non-invasive home } \\
\text { ventilation" } \\
\text { To describe the patients' } \\
\text { with ALS and their } \\
\text { caregivers' experience } \\
\text { of NIV }\end{array}$ & $\begin{array}{l}\text { Qualitative } \\
\text { Phenomenological } \\
\text { hermeneutic method } \\
\text { In-depth interviews }\end{array}$ & $\begin{array}{l}\text { Sweden } \\
\text { University hospital } \\
7 \text { patients ( } 5 \text { male), } 8 \text { care } \\
\text { supporters } \\
\text { Age } 45-75 \text { years }\end{array}$ & $\begin{array}{l}\text { Three main themes emerged } \\
\text { Getting to know the } \\
\text { ventilator } \\
\text { Embracing the ventilator } \\
\text { Being on the ventilator } \\
\text { Patients can effectively benefit } \\
\text { from improved sleep by NIV } \\
\text { Patients can experience several } \\
\text { problems connected to the } \\
\text { mask }\end{array}$ & $\begin{array}{l}\text { Some of the patients were } \\
\text { very ill and reluctant to } \\
\text { answer all questions; this } \\
\text { may have limited the } \\
\text { amount of data collected }\end{array}$ \\
\hline TORHEIM [49] & $\begin{array}{l}\text { "How to cope with the } \\
\text { mask? Experiences of } \\
\text { mask treatment in } \\
\text { patients with acute } \\
\text { chronic obstructive } \\
\text { pulmonary } \\
\text { disease-exacerbations" } \\
\text { To focus on important } \\
\text { aspects and issues } \\
\text { associated with BiPAP } \\
\text { mask treatment in acute } \\
\text { exacerbation of COPD } \\
\text { based on the } \\
\text { experiences of patients } \\
\text { and nurses }\end{array}$ & $\begin{array}{l}\text { Qualitative } \\
\text { Phenomenological } \\
\text { Approach } \\
\text { In-depth interviews }\end{array}$ & $\begin{array}{l}\text { Norway } \\
\text { University hospital } \\
\text { Purposive sampling } \\
5 \text { patients ( } 2 \text { males) } \\
\text { One focus group with } \\
8 \text { nurses } \\
\text { Age } 45-78 \text { years }\end{array}$ & $\begin{array}{l}\text { Patients have difficulties in coping } \\
\text { with mask } \\
\text { Patients felt tension between } \\
\text { dependence and autonomy } \\
\text { Patients feel confident in using } \\
\text { the mask when receiving } \\
\text { skilled help } \\
\text { Patients need breaks between } \\
\text { sessions to give some respite } \\
\text { from the pressure and pain of } \\
\text { the NIV mask }\end{array}$ & $\begin{array}{l}\text { Lack of generalisability due to } \\
\text { the population } \\
\text { The study was limited to only } \\
\text { one hospital } \\
\text { The study made no attempt to } \\
\text { reach thematic saturation, } \\
\text { which is a potential } \\
\text { methodological limitation }\end{array}$ \\
\hline
\end{tabular}


Table 2 Continued

\begin{tabular}{|c|c|c|c|c|c|}
\hline $\begin{array}{l}\text { First author } \\
\text { [ref.] }\end{array}$ & Topic, focus and questions & Paradigm and method & Setting and sample & Findings & Limitations \\
\hline TORHEIM [50] & $\begin{array}{l}\text { "How do patients with } \\
\text { exacerbated chronic } \\
\text { obstructive pulmonary } \\
\text { disease experience care } \\
\text { in the intensive care } \\
\text { unit?" } \\
\text { To gain insight into how } \\
\text { patient with advanced } \\
\text { COPD experience care in } \\
\text { the acute phase }\end{array}$ & $\begin{array}{l}\text { Qualitative } \\
\text { Phenomenological analysis } \\
\text { Semistructured interviews }\end{array}$ & $\begin{array}{l}\text { Norway } \\
\text { Hospital } \\
10 \text { patients ( } 5 \text { male) } \\
\text { Age } 45-85 \text { years }\end{array}$ & $\begin{array}{l}\text { Three central themes emerged: } \\
\text { Preserving the breath } \\
\text { of life } \\
\text { Vulnerable interactions } \\
\text { Opportunity for better } \\
\text { health } \\
\text { Patients experienced } \\
\text { themselves as being in a } \\
\text { state where life was } \\
\text { about to end } \\
\text { Patients were totally dependent } \\
\text { on technology } \\
\text { Lessening of anxiety in NIV } \\
\text { through several coping } \\
\text { strategies, and faith in one's } \\
\text { ability to cope with receive } \\
\text { greater focus when patients' } \\
\text { sense impressions are } \\
\text { interpreted and understood } \\
\text { by the nurse in a manner } \\
\text { which creates trust and the } \\
\text { NIV treatment may succeed }\end{array}$ & $\begin{array}{l}\text { The findings represent patient } \\
\text { experiences of an acute and } \\
\text { life-threatening condition; } \\
\text { therefore, most of the } \\
\text { patients were in an altered } \\
\text { mental state and did not } \\
\text { remember all from the } \\
\text { acute stage }\end{array}$ \\
\hline TYRReLL [31] & $\begin{array}{l}\text { "A preliminary study of } \\
\text { psychological factors } \\
\text { affecting patients' } \\
\text { acceptance of CPAP } \\
\text { therapy for sleep apnoea } \\
\text { syndrome" } \\
\text { To explore patients' } \\
\text { understanding and } \\
\text { experiences of their OSA } \\
\text { and of the CPAP therapy } \\
\text { and their reasons for } \\
\text { stopping }\end{array}$ & $\begin{array}{l}\text { Qualitative } \\
\text { Exploratory } \\
\text { Retrospective- } \\
\quad \text { semistructured } \\
\text { interviews and survey }\end{array}$ & $\begin{array}{l}\text { France } \\
\text { French respiratory } \\
\quad \text { homecare network } \\
\text { Purposive sample } \\
9 \text { patients ( } 8 \text { male) } \\
\text { Age } 32-70 \text { years }\end{array}$ & $\begin{array}{l}\text { Patients' understanding of illness } \\
\text { and CPAP treatment was } \\
\text { variable } \\
\text { Seven patients specified that they } \\
\text { abandoned CPAP treatment } \\
\text { because of their negative } \\
\text { experiences } \\
\text { Authors concluded that there was } \\
\text { a need for more } \\
\text { comprehensive psychological } \\
\text { evaluation in conjunction with } \\
\text { medical evaluation at the start } \\
\text { of CPAP in order to identify } \\
\text { factors associated with } \\
\text { successful and unsuccessful } \\
\text { adoption of CPAP therapy }\end{array}$ & $\begin{array}{l}\text { Only one female of out nine } \\
\text { patients was interviewed } \\
\text { Duration of interviews not } \\
\text { stated } \\
\text { Study interviewed patients } \\
\text { who abandoned CPAP after } \\
\text { several months of treatment } \\
\text { and excluded those who } \\
\text { abandoned it within days or } \\
\text { weeks; the views of patients } \\
\text { who abandoned the } \\
\text { treatment at an early stage } \\
\text { would have been interesting }\end{array}$ \\
\hline
\end{tabular}


Table 2 Continued

\title{
First author \\ [ref.]
}

Topic, focus and questions Paradigm and method

Setting and sample

Findings

Limitations

VAN de Mortel [21] "Client perceptions of the

polysomnography

experience and

compliance with

therapy"

To generate theory about clients' perceptions of polysomnography, and

the relationships

between these

perceptions and

compliance with therapy

\section{Veale [51]}

\section{To seek an in-depth} analysis of how patients live with sleep apnoea by allowing them an open discourse and analysing the text of their statements

\section{WilLman [52]}

\author{
“Experiences with CPAP \\ treatment in patients \\ with obstructive sleep \\ apnea syndrome and \\ obesity" \\ To describe patients' \\ experiences of CPAP \\ treatment in obese \\ individuals with \\ moderate-to-severe OSA \\ syndrome
}

Qualitative

Australia

Grounded theory approach

Hospital setting

Semistructured interviews 10 patients (8 male)
Qualitative

Retrospective discourse

analysis

Semidirective interviews

\section{France}

Pulmonary rehabilitation

unit, purposive sample

30 participants (sex not

given) of whom 15 were

commencing CPAP

Age 39-74 years
$17.7 \%$ of respondents hoped

\section{Qualitative Sweden}

Semistructured interviews Dept of Lung Medicine,

Uppsala University Hospital Consecutive sampling

15 patients $(8$ male)

Age 41-71 years
Compliance with therapy related

to the degree of benefit derived

by the client

In addition, there were

problems with the process of

diagnosis and follow-up that

impacted on client satisfaction

and may have influenced their

compliance

These findings have highlighted issues that have been used to generate theories that will be

tested in future research

Two questions explored the

difficulties with and long-term expectations of CPAP

CPAP was described as a

problem or nuisance with noise and nasal mask problems raised 21 times

CPAP users claimed better sleep on CPAP but expressed general dissatisfaction for a "miracle cure"

The authors acknowledged

that lower CPAP

compliance in this study

may be related to

difficulties involved in

operating a small regional

hospital with less resources

Assessment of patient

experiences focused on concerns living with OSA rather than CPAP

The use of discourse analysis is questionable; the approach places particularly heavy reliance on the insights and intuition of the researcher for interpreting the data

Experiences of CPAP use differed between individuals but common for all was the existence of both drawbacks and benefits

Difficulties in adapting to the CPAP may be the cause of many quitting

Some patients persisted through difficulties
Limited to participants with obesity

CPAP: continuous positive airway pressure; OA: oral appliance; NIV: noninvasive ventilation; MND: motor neurone disease; OSA: obstructive sleep apnoea; NZ: New Zealander; PAP: positive airway pressure; COPD: chronic obstructive pulmonary disease; ARF: acute respiratory failure; BiPAP: bilevel positive airway pressure; IPA: interpretative phenomenological analysis; QoL: quality of life; NHS: National Health Service; WCNN: Walton Centre for Neurology and Neurosurgery; UHA: University Hospital Aintree; ICU: intensive care unit; AECOPD: acute exacerbation of chronic obstructive pulmonary disease. ${ }^{\#}$ : Respironics, Murrysville, PA, USA. 
Fear

Fear in people undergoing NIV treatment was a recurrent theme. In all but four studies [38, 40, 42, 51], participants expressed a fear of being on NIV. From the studies, it appears there are a number of factors, which triggers fear in people with HRF undergoing NIV, which may lead to NIV rejection. Evidence indicates that patient fear is the most common disorder among NIV patients, and that it may interfere with the whole treatment process. In almost half of the studies, fear is also described as anxiety. None of the studies reviewed gave a clear definition of fear but it appears that fear is an unpleasant and uncomfortable feeling related to a certain source [46]. However, across the studies, fear was described by participants in various ways. Specific categories of fears described included fear of technology/mask, fear of death and dying, and fear of pain and suffering. The following section will explore these subthemes in more detail.

\section{Fear of technology}

A number of studies highlighted that most of patients with acute respiratory failure usually have a fear of technology, how it works and possible adverse effects [22, 23, 29, 39, 40, 43, 47]. Fear of technology was highlighted in the study by INGADÓTTIR and JONSDOTTIR [43], in which most of the participants experienced fear of the ventilation machine. There is a clear indication across the studies that discussed fear that patients view the NIV machine as a meaningless exercise and a burden due to the negative side of the experience, which then manifests as fear. Studies also revealed that participants questioned survival as well as relying on technology and others for survival, they felt out of control and reliant on technology, creating feelings of doom, fear of death and concerns over survival. The fact that they needed to be on an NIV machine meant that they felt at times that they would not survive.

\section{Fear of death and dying}

Another form of fear identified in many studies was the fear of death and dying. The majority of the studies found that patients' fears may be linked to iatrogenic outcomes and death, and that the fear of death and dying in patients using NIV is not uncommon [38, 44-46, 49, 50]. Studies also revealed that respiratory failure, choking, running out of air, discomfort, disease progression, and how and when they will die were the main fears that affected all the patients' decisions about NIV $[44,45,50]$. One study suggested that the fear of death in some patients not only manifests as a result of having the NIV mask strapped around their face but also as a result of not having the NIV treatment as a means of supporting their life [30].

\section{Fear of pain and suffering}

Some studies suggest that fear extends to fear of pain and suffering $[20,33]$. None of the studies described the fear of pain and suffering explicitly; however, a few of them highlighted fear of pain and suffering as a barrier to NIV treatment. A grounded theory study by SØRENSEN et al. [20] reported that as a result of the fear of pain and suffering, participants usually considered NIV discomfort intolerable as soon as they found that the treatment worsened their breathlessness, making them unable to cope with the sensation of being ventilated and restrained by the mask. Studies indicate that NIV side-effects such as claustrophobia, stomach distension, nose sores, throat dryness and nasal problems can be very frightening and unbearable for most NIV patients, and this was related to suffering [24-27, 33].

\section{Adaptation to the NIV machine}

Adaptation to the NIV machine was discussed in some of the studies and there is clear evidence that acceptance of NIV is a lengthy process that involves gradual orientation with the machine [22, 24, 27, 30, $34,39,41,45]$. Findings from these studies suggest that adaptation to the NIV machine can be very challenging and that it is intervention specific. Most the studies did not attempt to define adaptation in the context of NIV treatment. The few studies that attempted to define adaptation to the NIV machine described it with reference to adherence or tolerance, as these two concepts form an integral part of the intervention process $[21,31,52,54]$. Thus, from this given description and related discussions in other studies, adaptation in the context of NIV treatment may be defined as a gradual familiarisation process by which patients make alterations to conform to a newly introduced medical device.

Evident throughout all the studies was the fact that when patients are started on NIV treatment, they usually have difficulties and troubles in becoming accustomed to the machine. These difficulties are related to significant air leaks, feelings of claustrophobia, aerophagia, presence or risk of facial injuries and respiratory distress $[35,36,38,51]$

In one study, all the patients who took part in the research chose not to continue using their CPAP machine as prescribed because of various problems that they encountered, such as mask tightness, skin lesions, noise, leaks and airway lesions as result of the treatment [31]. 
However, regardless of the difficulties and troubles that most of the participants across the studies encountered at the inception of the treatment, they persisted through these difficulties $[31,34,39,46,48]$. Studies in this review suggest that persistence and tolerance were two mechanisms adopted by participants in the process of developing an adjustment to being attached to the NIV machine. Furthermore, others studies indicate that adaptation or acceptance of the NIV machine can be promoted by developing specific education about adverse effects and benefits of the treatment, which patients need to be aware of prior to being started on NIV treatment $[41,45,52]$.

\section{Decision making}

The present literature review specifically addressed experiences of patients with acute respiratory failure on NIV treatment, and did not extend to studies which focused primarily on decision making. Nonetheless, the issue of decision making was apparent in some of the papers reviewed, particularly with regard to treatment preference [45]. Across the studies, there is no clear definition of decision making or description of the process of decision making. However, it appears that decision making is important and that it is about recognising patients' autonomy, respect and giving the patients the right to have a final say in determining how they wish to be treated. Decision making has been described widely as an important component of the relationship between healthcare professionals and patients, and was an aspect of some of these studies $[20,45,46]$.

Interestingly, the majority of studies found that patients are not always involved in decisions relating to their NIV [30, 43, 46, 55]. It appears that the choice about ventilation is always made for patients by healthcare professionals, families or carers, without them being fully involved. In some studies, there is a consensus among the participants that the decision-making process is not simple, especially when participants felt that they were being led onto the treatment without making a final decision. In one particular study [46], most participants who took part in the interviews revealed that they were relieved to be able to make a decision to discontinue the NIV treatment if they found ventilation intolerable or did not see sufficient benefit, thus implying that it is important to allow the patients to retain the right to make their own decision by weighing up evidence and reaching their own conclusions.

Similarly, as in other studies, the finding of PIGGIN [46] in relation to decision making confirm that patients are under-consulted and they lack understanding of the whole process of decision making [34, 37, 45]. Arguably, this evidence may justify why another study suggested the need for patients receiving NIV therapy to have better understanding and involvement with their treatment in order to promote them as active participants in their own care [47]. The Declaration of Helsinki has informed recent human rights in relation to patient rights and, currently, healthcare policy and guidelines direct clinicians to engage in shared decision making [55]. However, findings from some, but not all, of the studies raise concerns about the process of gaining informed consent from NIV patients. From the studies that explored decision making, the process has been widely described as an important component of the relationship between healthcare professionals and patients. However, there is consistency among these studies, which appear to suggest that patients are under-consulted when it comes to making decision about their treatment. From all these studies, none appears to give a clear definition of decision making or the process of decision making; nevertheless, it appears that decision making in NIV treatment refers to patient ownership over treatment preferences and the decision to ventilate.

\section{The need for information}

The need for information among NIV patients with acute respiratory failure is well documented in most of the studies. Evidence from these studies suggest that when people with acute respiratory failure become ill, as seen in other illnesses, they develop much interest in knowing more about their condition, how it will be managed and the impact that will have on their wellbeing [25, 35, 36, 39, 41, 46]. It is also evident from the studies that information is regarded by patients as a means to feel empowered and in control [22, 37-39, 41, 52]. Based on the literature, information need in NIV treatment may be defined as a state or process that begins when a patient becomes aware that there is disparity between the information and knowledge available to manage their illness and the actual solution of the illness. However, in information-related themes, participants who took part in most of the studies raised concerns with the manner in which diagnosis was delivered. The concerns were directed at the communication style of the healthcare professional and systemic issues in experiencing convoluted pathways to arrive at a diagnosis. Findings suggest that healthcare professionals do not always give their patients enough information about their illness, prognosis and the nature of treatment intervention.

Based on participants' narratives, it appears that patients are more interested in knowing how the NIV machine works, the likely duration of the intervention or any other alternative intervention. However, it appears that healthcare professionals do not routinely provide such information to NIV patients. Patients feel that healthcare professionals provide them with "too little" information, which then leave them with no option but to resort to seeking the information themselves from varied sources, such as the internet [22, 32]. 
Findings suggested that having access to information assists the patient in making decisions and overcoming barriers to adapt to the device [40].

Nevertheless, it is also interesting to note that NIV patients are very particular with the amount of information that they wish to receive; for instance, some participants in the study by SHOUKRY et al. [32] felt that they were being bombarded with "too much" information, which they thought was not necessary, especially at a time where they were still assimilating their diagnosis. The findings of BAKKER et al. [36] and LEMoignan and ElLS [45] suggest that patients do not want information about their treatment before it is needed to make decisions, because information tends to discourage them. Furthermore, the studies revealed that the positivity aspect of information was an issue rated more highly by patients than by healthcare professionals. This may then suggest that healthcare professionals overlook the patients' need for information, which could then affect treatment adherence in NIV patients.

\section{Relationship with healthcare professionals}

A number of studies that examined patients' experiences of NIV in hospital settings make reference to healthcare professionals, as they are an integral part of the support structure. Nurses and doctors are essential for the care and management of patients on NIV because they provide 24-h, direct care and support, and their collaboration with patients may influence the success of NIV [35, 49]. Sørensen et al. [20] refer to patient-healthcare professional relationships in terms of patient involvement, patient participation in decisions, trust, respect and professional intimacy, and the appropriate use of authority or power.

Across the studies, it appears that the relationship between healthcare professionals and patients is characterised by various forms of asymmetry. These studies indicate that healthcare professionals may have both theoretical and practical knowledge; patients usually have neither. Studies also reveal that at times, healthcare professionals may need to act in the best interest of a patient when considering NIV; however, some patients viewed this as an act of being controlled, characterised by components of coercion and pressure [20,51]. Nevertheless, there is a general consensus across the studies that patients often relinquished control of their treatment to healthcare professionals, but they were still able to interact positively with healthcare professionals and to take part actively in their treatment [44, 45].

Results from seven studies suggest that when patients are diagnosed with acute respiratory failure, they usually put their lives, and often decision making, in the hands of healthcare professionals [24, 25, 30, 35, 45-47]. It is evident from findings across these studies that breathlessness and being on an NIV machine make patients perceive that they have to be completely dependent on clinicians during the intervention. These findings may imply that patients find themselves in a situation characterised by a low degree of patient power and patient participation. Nevertheless, it was also found that although the patients trusted clinicians in helping them with NIV, there were care deficiencies: situations in which they felt neglected and not involved in their treatment. In the conclusions of their study, SøRENSEN et al. [20] suggest that in future, research projects should investigate the effect of patient-nurse interactions to promote our understanding of how to influence tolerance and succeed with NIV.

\section{Discussion}

This review illustrates the nature of experience that people undergoing NIV treatment face. The six themes give a holistic description of the experience of patients undergoing NIV, which includes benefits of NIV, the psychological reactions to NIV treatment, coping strategies, decision making, provision of information, and the relationship with healthcare providers.

This review reveals that the benefits of NIV are well documented. NIV is effective and improves the quality of life for people with respiratory failure [53]. However, the review showed that participants were more interested in sharing the negative aspects of being on the NIV machine rather than the positive aspects of the machine. Thus, the review shows that fear, sometimes described as anxiety, is the most common disorder among NIV patients and, as such, interferes with the whole treatment process. Patients usually experience fear due to not only being on the NIV machine but also fear of death and dying, and pain and suffering. It is clear that fear of technology has an impact on how patients perceive NIV treatment. There is a general consensus across the studies that the fear, be it of technology, death and dying, or pain and suffering, is often overlooked by healthcare providers, and that when a patient has intense fear, it can be very damaging to their health because the patient may not be willing to use the machine [30]. Perhaps healthcare professionals need to devise alternative measures that can assist patients to alleviate the fear in NIV treatment. Literature indicates that to date, there have been no qualitative studies conducted to investigate the fear of NIV machines in older people.

Challenges associated with adaptation to the NIV machine were a significant finding in this review. Due to various problems that patients encounter as a result of the treatment, such as mask tightness, skin lesions, 
noise, leaks and airway lesions, most patients find it difficult to adapt to the NIV machine. Thus, patients often have a negative experience of the machine. However, some patients are not deterred by these problems; instead, they find a need to persist through difficulties in order to survive. Positive coping styles, such as being actively engaged with problems of adaptation and acceptance, could be key factors for psychological wellbeing and better adherence to NIV [40]. Furthermore, there is a realisation that adaptation or acceptance of the NIV machine can be promoted by developing specific education about adverse effects and benefits of the treatment, which patients need to be aware of prior to being started on NIV treatment [39]. Thus, healthcare professionals need to provide more information and education to NIV patients in order to promote NIV tolerance.

Another significant finding in this review was that the choice about ventilation is always made for patients by healthcare professionals, their families or carers, without them being fully involved. Patients feel that healthcare professionals do not include them in decision making and that they are often put onto the treatment without making a final decision [49]. Patients can feel relieved to be able to make a decision to discontinue the NIV treatment if they find ventilation intolerable or do not see sufficient benefit. Results pertaining to decision making also revealed that patients need to be consulted regarding treatment preference, so that they can decide a preferred mode of NIV treatment for themselves [45]. Lack of treatment involvement in decision making leaves patients with no other option but to comply with the available treatment method.

Furthermore, this review also revealed that the need for information was an issue rated more highly by patients than by healthcare professionals. Patients need information in order to inform their decision and they regard information as fundamental. Healthcare providers should therefore play a pivotal role in providing such information. Findings clearly suggest that patients are likely to accommodate NIV treatment if they are educated and given enough information on NIV prior to treatment inception [37].

The importance of the relationship between NIV patients and healthcare professionals is acknowledged. Trust is essential in the relationship between the healthcare professional and NIV patient. Trust between patient and nurse is necessary for reducing patients' anxiety, and enabling them to regain a sense of control.

\section{Strengths and limitations}

All the studies in this review are of high quality and authored by experts in the field. They were conducted in various countries, populations and situations, and different sociocultural structures, albeit that they were limited to studies written in English. Even though studies written in other languages were not considered, it seems sensible to affirm that the findings of this study can be applied to other countries in a similar healthcare context. Nevertheless, the transferability of the review is restricted by the nature of included studies: most include participants receiving NIV as CPAP for diseases such as sleep apnoea and motor neurone disease, except for two that considered patients receiving NIV as BiPAP.

\section{Conclusion}

For people with HRF using NIV treatment, the experience of being on an NIV machine is unexpected and can be stressful. Underlying much of the reviewed studies was participants' desire for more information or other interventions that could make their experience much better.

This review identified the need for research into the experiences of NIV in older people with HRF, as the majority of the studies in this review focused on mixed populations aged 27-85 years. This suggests that our knowledge of NIV treatment in patients with HRF is predominantly based on the experiences of patients of varied age groups recruited from communities rather than older people admitted in hospital. It is therefore useful to conduct a study that explicitly focuses on HRF in people aged 65 years or more who are admitted for the purpose of NIV treatment, in order to better understand acceptance issues in this population. This may give healthcare professionals the basis to implement new strategies in NIV provision and the exploration of the applicability of age specific supportive care NIV guidelines.

\section{Acknowledgements}

All authors were responsible for the overall study conception and study design, analysed the data and drafted the manuscript. All authors approved the final manuscript.

\section{References}

1 Mas A, Masip J. Noninvasive ventilation in acute respiratory failure. Int J Chron Obstruct Pulmon Dis 2014; 9: $837-852$.

2 Rose L, Gerdtz MF. Review of non-invasive ventilation in the emergency department: clinical considerations and management priorities. J Clin Nurs 2009; 18: 3216-3224.

3 Moore D. Preventing acute hypercapnic respiratory failure in COPD patients. Nurs Stand 2013; 27: 35-41. 
Fournier M. Caring for patients in respiratory failure: even if you don't work in an ICU, you're likely to encounter patients in respiratory failure. Am Nurse Today 2014; 9: 6-18.

5 Lightowler JV, Wedzicha JA, Elliott MW, et al. Non-invasive positive pressure ventilation to treat respiratory failure resulting from exacerbations of chronic obstructive pulmonary disease: Cochrane systematic review and meta-analysis. BMJ 2003; 326: 185.

6 Keenan SP, Gregor J, Sibbald WJ, et al. Noninvasive positive pressure ventilation in the setting of severe, acute exacerbations of chronic obstructive pulmonary disease: more effective and less expensive. Crit Care Med 2000; 28: 2094-2102.

7 Salepci B, Caglayan B, Kiral N, et al. CPAP adherence of patients with obstructive sleep apnea. Respir Care 2013; 58: 1467-1473.

8 Yang MC, Lin CY, Lan CC, et al. Factors affecting CPAP acceptance in elderly patients with obstructive sleep apnea in Taiwan. Respir Care 2013; 58: 1504-1513.

9 Smith AT, Davidson PM, Jenkins CR, et al. Life behind the mask: the patient experience of NIV. Lancet Respir Med 2015; 3: 8-10.

10 Wright K, Golder S, Lewis-Light K. What value is the CINAHL database when searching for systematic reviews of qualitative studies? Syst Rev 2015; 4: 104.

11 Sandelowski M. A matter of taste evaluating the quality of qualitative research. Nurs Inq 2015; 22: 86-94.

12 Sale JEM. How to assess rigour... or not in qualitative papers. J Eval Clin Pract 2008; 14: 912-913.

13 Rolfe G. Validity, trustworthiness and rigour: quality and the idea of qualitative research. J Adv Nurs 2006; 53: 304-310.

14 Daly J, Willis K, Small R, et al. A hierarchy of evidence for assessing qualitative health research. J Clin Epidemiol 2007; 60: 43-49.

15 Thomas J, Harden A. Methods for the thematic synthesis of qualitative research in systematic reviews. BMC Med Res Methodol 2008; 8: 45.

16 Schaefer IL, Dorschner S. "Fur mich ist Lebensqualitat, selbstandig handeln zu konnen..." Wie erleben COPD-Patienten ihre Heimbeatmung? Eine qualitative Studie. ["Quality of life means acting independently”. How do COPD-patients experience non-invasive ventilation? A qualitative study.]. Pflege 2005; 18: $159-168$.

17 Matthews H. The patients' experience of NIV. A phenomenological study. Thorax 2010; A143-A144.

18 Moher D, Shamseer L, Clarke M, et al. Preferred reporting items for systematic review and meta-analysis protocols (PRISMA-P) 2015 statement. Syst Rev 2015; 4: 1

19 Moher D, Liberati A, Tetzlaff J, et al. Preferred Reporting Items for Systematic Reviews and Meta-Analyses: the PRISMA statement. PLoS Med 2009; 6: e1000097.

20 Sørensen D, Frederiksen K, Groefte T, et al. Striving for habitual well-being in noninvasive ventilation: a grounded theory study of chronic obstructive pulmonary disease patients with acute respiratory failure. J Clin Nurs 2014; 23: $1726-1735$.

21 van de Mortel TF, Laird P, Jarrett C. Client perceptions of the polysomnography experience and compliance with therapy. Contemp Nurse 2000; 9: 161-168.

22 Hu ST, Yu CC, Lee PS, et al. Life experiences among obstructive sleep apnoea patients receiving continuous positive airway pressure therapy. J Clin Nurs 2014; 23: 268-278.

23 Broström A, Fridlund B, Ulander M, et al. A mixed method evaluation of a group-based educational programme for CPAP use in patients with obstructive sleep apnea. J Eval Clin Pract 2013; 19: 173-184.

24 Sawyer AM, Deatrick JA, Kuna ST, et al. Differences in perceptions of the diagnosis and treatment of obstructive sleep apnea and continuous positive airway pressure therapy among adherers and nonadherers. Qual Health Res 2010; 20: 873-892.

25 Lindahl B, Sandman PO, Rasmussen BH. Meanings of living at home on a ventilator. Nurs Inq 2003; 10: 19-27.

26 Lindahl B, Sandman PO, Rasmussen BH. On being dependent on home mechanical ventilation: depictions of patients' experiences over time. Qual Health Res 2006; 16: 881-901.

27 Lindahl B, Sandman PO, Rasmussén BH. On becoming dependent on home mechanical ventilation. J Adv Nurs 2005; 49: 33-42.

28 Dimech A. Critical care patients' experience of the helmet continuous positive airway pressure. Nurs Crit Care 2012; 17: 36-43.

29 Ando H. Exploring reasons for declining and withdrawing from non-invasive ventilation among motor neurone disease patients: an interpretative phenomenological analysis. MPhil thesis. University of Liverpool, Liverpool, UK, 2010.

30 Ando H, Chakrabarti B, Angus RM, et al. Experience of long-term use of non-invasive ventilation in motor neuron disease: an interpretative phenomenological analysis. BMJ Support Palliat Care 2014; 4: 50-56.

31 Tyrrell J, Poulet C, Pe Pin JL, et al. A preliminary study of psychological factors affecting patients' acceptance of CPAP therapy for sleep apnoea syndrome. Sleep Med 2006; 7: 375-379.

32 Shoukry G, Wong K, Bartlett D, et al. Treatment experience of people with obstructive sleep apnoea seeking continuous positive airways pressure device provision through community pharmacies: a role for pharmacists? Int J Pharm Pract 2011; 19: 318-327.

33 Almeida FR, Henrich N, Marra C, et al. Patient preferences and experiences of CPAP and oral appliances for the treatment of obstructive sleep apnea: a qualitative analysis. Sleep Breath 2013; 17: 659-666.

34 Ando H, Williams C, Angus RM, et al. Why don't they accept non-invasive ventilation? Insight into the interpersonal perspectives of patients with motor neurone disease. Br J Clin Psychol 2015; 20: 341-359.

35 Ayow TM, Paquet F, Dallaire J, et al. Factors influencing the use and nonuse of continuous positive airway pressure therapy: a comparative case study. Rehabil Nurs 2009; 34: 230-236.

36 Bakker JP, O’Keeffe KM, Neill AM, et al. Continuous positive airway pressure treatment for obstructive sleep apnoea: Maori, Pacific and New Zealand European experiences. J Prim Health Care 2014; 6: 221-228.

37 Ballangrud R, Bogsti WB, Johansson IS. Clients' experiences of living at home with a mechanical ventilator. $J$ Adv Nurs 2009; 65: 425-434.

38 Broström A, Nilsen P, Johansson P, et al. Putative facilitators and barriers for adherence to CPAP treatment in patients with obstructive sleep apnea syndrome: a qualitative content analysis. Sleep Med 2010; 11: 126-130.

39 Dickerson SS, Akhu-Zaheya L. Life changes in individuals diagnosed with sleep apnea while accommodating to continuous positive airway pressure (CPAP) devices. Rehabil Nurs 2007; 32: 241-250. 

114-122.

41 Fung $\mathrm{CH}$, Igodan U, Alessi C, et al. Human factors/usability barriers to home medical devices among individuals with disabling conditions: in-depth interviews with positive airway pressure device users. Disabil Health J 2015; 8: 86-92.

42 Gale NK, Jawad M, Dave C, et al. Adapting to domiciliary non-invasive ventilation in chronic obstructive pulmonary disease: a qualitative interview study. Palliat Med 2015; 29: 268-277.

43 Ingadóttir TS, Jonsdottir H. Technological dependency - the experience of using home ventilators and long-term oxygen therapy: patients' and families' perspective. Scand J Caring Sci 2006; 20: 18-25.

44 Kvangarsnes M, Torheim H, Hole T, et al. Narratives of breathlessness in chronic obstructive pulmonary disease. J Clin Nurs 2013; 22: 3062-3070.

45 Lemoignan J, Ells C. Amyotrophic lateral sclerosis and assisted ventilation: how patients decide. Palliat Support Care 2010; 8: 207-213.

46 Piggin LH. The experience of non-invasive ventilation in motor neurone disease: a qualitative exploration. PhD thesis. University of Liverpool, Liverpool, UK, 2011

47 Slater J. An investigation of the experiences of patients receiving non-invasive ventilation for acute exacerbations of chronic obstructive pulmonary disease. MSc thesis. Cardiff University, Cardiff, UK, 2011.

48 Sundling IM, Ekman SL, Weinberg J, et al. Patients' with ALS and caregivers' experiences of non-invasive home ventilation. Adv Physiother 2009; 11: 114-120.

49 Torheim H, Gjengedal E. How to cope with the mask? Experiences of mask treatment in patients with acute chronic obstructive pulmonary disease-exacerbations. Scand J Caring Sci 2010; 24: 499-506.

50 Torheim H, Kvangarsnes $\mathrm{M}$. How do patients with exacerbated chronic obstructive pulmonary disease experience care in the intensive care unit? Scand J Caring Sci 2014; 28: 741-748.

51 Veale D, Poussin G, Benes F, et al. Identification of quality of life concerns of patients with obstructive sleep apnoea at the time of initiation of continuous positive airway pressure: a discourse analysis. Qual Life Res 2002; 11: 389-399.

52 Willman M, Igelström H, Martin C, et al. Experiences with CPAP treatment in patients with obstructive sleep apnea syndrome and obesity. Adv Physiother 2012; 14: 166-174.

53 Piepers S, van den Berg JP, Kalmijn S, et al. Effect of non-invasive ventilation on survival, quality of life, respiratory function and cognition: a review of the literature. Amyotroph Lateral Scler 2006; 7: 195-200.

54 Baxter SK, Baird WO, Thompson S, et al. The initiation of non-invasive ventilation for patients with motor neuron disease: patient and carer perceptions of obstacles and outcomes. Amyotroph Lateral Scler Frontotemporal Degener 2013; 14: 105-110.

55 Association WM. World Medical Association Declaration of Helsinki: ethical principles for medical research involving human subjects. JAMA 2013; 310: 2191-2194. 